\title{
A Mixed-Design Study on Development of Spatial Perception Skills in Life Science Course
}

\author{
Nur ÜTKÜR GÜLLÜHAN 1 \\ Istanbul University-Cerrahpaşa, Istanbul \\ TURKEY
}

\author{
Tuğçe EMRAL2 \\ Ministry of National Education, Istanbul \\ TURKEY
}

${ }^{1}$ Corresponding author: Assoc. Prof. Dr.. Istanbul University-Cerrahpaşa, Hasan Ali Yucel Education Faculty, Department of Primary
School Education, Buyukçekmece Campus, Istanbul, TURKEY. nur.utkur[at] iuc.edu.tr. ORCID: 0000-0003-2062-5430
2 Teacher. Ministry of National Education, Istanbul, TURKEY. emral670[at] gmail.com. ORCID: 0000-0002-8028-305X

\section{Abstract}

This study aimed to examine how instruction of geography subjects in primary school third-grade Life Studies course with several methods affects students' attitudes toward this course and their spatial perception skills. To that end, the study was designed with exploratory sequential mixed methods approach. Two third-grade classes at a public school on the European side of Istanbul province were randomly assigned as experimental and control groups. After the Life Science Attitude Scale and the open-ended perception questionnaire were administered to the both groups as pretests, their readiness were found to be similar. The groups were given a education that included geography subjects and aimed to improve spatial perception skills for eight hours. In the experimental group, the education involved the instruction of geography subjects in Life Science course by using methods such as case study, drama, and questionanswer whereas it involved the instruction of the same geography subjects with the methods included in the textbook in the control group. Later, the scale and questionnaire were read ministered as posttests. The quantitative data of the study were analyzed with Mann-Whitney U and Wilcoxon Signed Ranks tests, and the qualitative data were subjected to the content analysis which was made using codes, categories, and themes. Consequently, Life Science Attitude Scale scores of the experimental group were found to be significantly higher than the control group. Moreover, as shown by results of the open-ended perception questionnaire, the experimental group had a better grasp of the concepts about spatial perception skills compared to the control group.

\section{Keywords}

Geography, Spatial Perception Skills, Life Science Course, Primary School Third Grade. 
Humans exist in a space in every domain of life. Spatial is where humans perform all their activities and have their experiences. Space bears different meanings depending on how it is perceived and evaluated by those who occupies it (Tümertekin \& Özgüç, 2004). Ability to perceive the space and attribute different meanings to it is of importance especially for children of early ages. Primary and secondary school is considered an important step in providing children with the spatial perception (Parker, 2001) because this skill, which is taught at early ages within the scope of geographical education, helps children have better understanding of their surroundings, society and country. Moreover, with this skill, children can also notice what happens around and gain the ability to read maps/plots and to find direction (Ablak \& Aksoy, 2018).

Indeed, regarding the Life Science curricula that have been employed in Turkey to date, map and direction literacy has been maintained and considered important in all revised curricula (Kuzey, 2017; Sönmez \& Aksoy, 2013). Life Science is a course, which is given in primary school first, second, third grades in Turkey, and involves elements from child's life. It is an interdisciplinary course that progresses as a mixture of Social Studies and Science courses (MoNE, 2018). Life Science course include subjects of school, home, family, and immediate surroundings. It is important for students to get acquainted with their surroundings through their experience in the course. Those subjects start from child's immediate surroundings and intensify as time goes on. The subjects concentrate on how students have made meaning of life from their birth to school age and from what kind of a perspective they interpret that process (Kabapınar, 2016; MoNE, 2018).

With the constructivist approach included in educational programs in Turkey as of 2005, spatial perception skill, alongside many others, have become one of the skills to provide students with (MoNE, 2005). The constructivist theory is based on the belief that students actively create and interpret the information and reorganize it by their preliminary knowledge. By the way, it is aimed to form an active learning environment (Brooks \& Brooks, 1999; Schunk, 2011). A teaching approach in which student takes an active role in the learning process, learns by doing, experiencing and at first hand, and the information learned is retentive is thought to be the most effective method (Eaton, 1998). It is understood that content of Life Science course, which is shaped around the constructivist theory, and the current 2018 curriculum involve subskills of spatial perception skill. These are "drawing a plot of classroom and school, giving directions for home, knowing about characteristics of the place where one lives and is present, and pointing one's country, capital and place of residence on the map and globe" (MoNe, 2018).

With Life Science course, it is aimed that students get to know their surroundings, society and country. Spatial perception skill is of great importance in those objectives. How students get acquainted with their surroundings, society and country starts with spatial perception skill (MoNe, 2018). In Life Science course, students are expected to know about the nature, people in their vicinity, institutions, events, and phenomena and to acquire the qualities for adapting to the society. This course takes its source from student's individual and social environment. How students associate what they learn with their own experiences and put it into practice in their own life allows them to learn by doing/experiencing. Getting to 
know their environment and noticing the problems are important for students to solve the problems and create a better society (Kabapınar, 2016).

It is observed in the literature that there are studies on spatial perception skills (Ablak \& Aksoy, 2018; Aktürk, Yazıcı \& Bulut, 2013; Kuzey, 2020; Safi, 2010), map using (Akar, 2008; Akengin, Tuncel \& Cendek, 2016; Kızılçaoğlu, 2007; Kuzey, 2017; Pala \& Başıbüyük, 2020; Sönmez \& Aksoy, 2013; Witham-Bednarz, Acheson \& Bednarz, 2006), navigation (Demirbaş, Aydınözü \& Demir, 2020; Demirkaya, Çetin \& Tokcan, 2004), and plot reading (Bahar, Sayar \& Başıüyük, 2010) within the scope of Social Science course. However, no mixed-design study was observed in the literature on the effect of education provided to primary school students on students' spatial perception skills in the Life Science course. Thus, it is foreseen that this study will fill an important gap in the literature.

In the study, it was aimed to examine how the instruction of geography subjects in the primary school third-grade Life Science course with several methods and techniques affects students' spatial perception skills in this course and their attitudes toward the Life Science course. To that end, the following questions were answered in an attempt:

1. Is there a significant difference between pretest and posttest scores of the experimental group students?

2. Is there a significant difference between pretest and posttest scores of the control group students?

3. Is there a significant difference between posttest scores of the experimental and control group students in the Life Science Attitude Scale?

4. What are the differences between pre- and post-education results of the openended perception questionnaire for the students in the experimental and control groups?

\section{Methodology}

\section{Research Design}

The study applied the exploratory sequential mixed methods approach, which includes both quantitative and qualitative methods. In this design, qualitative data are collected to further understand the quantitative data. Qualitative data are designed to help explain the quantitative data obtained in the beginning (Creswell \& Plano-Clark, 2015). The reason why this design was preferred is to support quantitative data and to use qualitative data to explain their causes in the research.

Accordingly, quantitative methods were applied to explore how the education that included geography subjects in the Life Science course affected students' attitudes toward Life Science course. In the qualitative part of the research, "pretestposttest control group design" was used. In this design, participants are unbiasedly assigned to two or more intervention conditions and a pretest is administered. Next, intervention conditions are employed, and finally, a posttest is administered (Christensen, Johnson \& Turner, 2015). 
In this study, additionally, the qualitative research method was applied to determine the progress of students' spatial perception skills in the period between pre- and post- education. The qualitative research method used in the study is case study. It is a system of case description in which the researcher collects detailed information on a real-life, current situation or multiple limited situations within a given time via several information resources (Creswell, 2015). By nature of this study, this is a suitable research design for the qualitative part.

\section{Study group}

The study was conducted in a public school on the European side of İstanbul, Turkey in the academic year of 2020-2021. Purposive sampling method was used for choosing the classes in the study. Purposive sampling focuses on informationrich situations which will shed light on the targeted questions (Patton, 2004).

Primary school third-graders were chosen in this study since the Life Science course is given for the last time in the third grade among primary school grade levels. Since age groups of third-graders would be higher compared to first- and second-graders, it was thought that more effective answers would be received for the questions. For this purpose, it was decided to work with third grade primary school in this school. Then, the Life Science Attitude Scale (LSAS) was applied to the 3rd grades, which are five classes in the school. Two classes were selected, with no significant difference between scale scores. These classes were randomly assigned as experimental and control groups.

There are 21 students in the experimental group and 21 students in the control group. The experimental group involves 12 boys and 9 girls and the control group is composed of 11 boys and 10 girls. To see whether these two groups had similar attitudes toward Life Science course, the LSAS was administered as pre-test. The data obtained are given in Table 1.

Table 1

Mann-Whitney U Test Results for Pretest Scores of Groups

\begin{tabular}{llllll}
\hline Group & $\mathrm{n}$ & Mean Rank & Sum of Ranks & $\mathrm{U}$ & $\mathrm{p}$ \\
\hline Experimental & 21 & 22.29 & 468.00 & 204.00 & \multirow{2}{*}{.676} \\
Control & 21 & 20.71 & 435.00 & & \\
\hline
\end{tabular}

$\mathrm{p}>.05$

As seen in Table 1, Mann-Whitney $U$ test was applied to determine whether there was a significant difference between groups' attitudes toward Life Science course before the education performed with the experimental and control groups. Mean scores of attitude were found to be 22.29 for the experimental group and 20.71 for the control group. The difference between groups' attitude scores was found to be statistically non-significant ( $U=204.00, p=.676, p>.05)$. It was accordingly concluded that the groups had similar attitudes toward Life Science course. In addition, the groups were found to have similar readiness levels in the pretest results of the openended perception questionnaire that was administered to determine their spatial perception skills, and then, the research was commenced. Required ethical permissions were received for the study from the principal, the classroom teachers, the students, and parents of the students. 


\section{Data Collection Tools}

The Life Science Attitude Scale was used for collecting the quantitative data while an open-ended questionnaire was applied to collect the qualitative data in the study.

Life science attitude scale (LSAS). The scale was developed by ZayimoğluÖztürk and Coşkun (2015) to measure student attitudes toward Life Science course. The factor analysis performed to achieve validity of the scale found a Kaiser-MeyerOlkin (KMO) value of 0.906. A value of 2431.319 was found in Bartlett's Test of Sphericity $(\mathrm{p}<.01)$. For the total scale, Cronbach's Alpha reliability coefficient was found to be 0.747 . Consequently, this scale proved to be a valid and reliable measure for use in identifying attitudes of primary school students.

Open-ended perception questionnaire. An open-ended perception questionnaire was used to collect qualitative data in the study. This questionnaire was administered to identify students' pre-and post- education perceptions of their spatial perception skills. The pre-education questionnaire is composed of five questions while the post-education questionnaire comprises of six questions. The questions aim to determine student opinions on geography and spatial perception before and after the education, to find out which tools are used in Life Science course for perceiving the space and which subjects are included in Life course about spatial perception. The question on the subjects about spatial perception skills in Life Science course was included in the posttest questionnaire.

When deciding on the questionnaire items, faculty members who specializes in the field were asked for opinion to achieve validity. The questions were finalized in line with the views of third-grade teachers in the school where the procedures were employed. Opinions of 8 experts in total ( 3 faculty members and 5 classroom teachers) were subjected to Lawshe's content validity test. Content validity indices of the items were calculated to ensure that they served the purpose of measuring. Content validity index was determined to be 0.90 for the questionnaire items. As suggested by Lawshe (1975), once this value is above 0.78 for 8 experts, the items are considered valid (as cited in Yurdugül, 2005). Some of the questions were revised in line with the expert opinions. Accordingly, the question on the subjects about spatial perception skill in Life Science course was included in the posteducation perception questionnaire, it was omitted from the post-education questionnaire since the students undoubtedly did not know anything about the question.

\section{Data Collection Process}

LSAS was administered to the experimental and control group as pretest before the education was performed. Then, in the education, the geography subjects in Life Science course were instructed with several methods (case study, drama, and question-answer) for the experimental group whereas the subjects were instructed with the methods provided in the Life Science textbook for the control group.

This education was performed during Life Science courses in eight hours in total (four hours for each of the groups). With each learning outcome accounting for two hours, course plans and worksheets were prepared based on the learning outcomes and subjects included in the primary school third-grade textbook in Table 2. 
Ütkür Güllühan, N.; Emral, T. (2021). A mixed-design study on development of spatial perception...

Table 2

Learning Outputs and Subjects

\begin{tabular}{ll}
\hline Learning outcome & Subject name \\
\hline $\begin{array}{l}\text { LS.3.1.5. Student draws a plot of his/her classroom } \\
\text { and school. }\end{array}$ & I Draw a Plot \\
\hline $\begin{array}{l}\text { LS.3.2.3. Student draws a plot of the place where } \\
\text { his/her home is located. }\end{array}$ & Where is Our Home? \\
\hline $\begin{array}{l}\text { LS.3.4.1. Student introduces traffic signs. } \\
\begin{array}{l}\text { LS.3.6.3. Student finds directions by applying the } \\
\text { nature. }\end{array}\end{array}$ & I Find Get to Know Traffic Signs \\
\hline
\end{tabular}

In each step of preparing the education performed with the experimental group, faculty members who specializes in the field were asked for opinions. The experts were interviewed particularly about teaching the spatial perception skill with multiple methods. The Lawshe technique was used to determine the validity of the education and whether it was suitable for the purpose.

Activities were purposively organized in accordance with the expert opinions. Opinions of 8 experts in total were received and subjected to Lawshe's (1975) content validity test (as cited in Yurdugül, 2005). Each stage and activity in the education was regarded as an item, and their content validity indices were calculated. A content validity index of 0.95 was calculated for the items. Consequently, the education was found to be valid for reflecting the spatial perception skills in geography subjects of Life Science course.

Since it was a pandemic period, this process of training was carried out online. A brief summary of the education steps and properties are given below:

1) In the subject 'I Draw a Plot', activities were performed to enable students to learn the concepts of plot and bird's eye view and contribute to their spatial perception skills. These activities included:

- Forming a classroom environment with matchboxes,

- Presentation of a simulation for spatial perception,

- Case reading about the exploration of plots used in everyday life and applying the plots,

- Finalizing the course with questions and answers.

2) In the subject 'Where is Our Home?', a case was applied and questions were asked so that students could feel the need to use a plot. With a plot image and questions about the image, activities were performed to develop students' spatial perception skills. These activities included:

- Applying a case and making students feel the need to use a plot,

- Developing the spatial perception skill by using a plot,

- Asking several analysis questions about the case text and receiving the answers,

- Completing the unfinished text of a case. 
3) In the subject 'Let's Get to Know Traffic Signs', the drama method was employed to represent the use of traffic signs in an area of life. An image of street was created, and activities were performed about where traffic signs could be found around homes of the students and what the signs can do. With activities that the students can adapt to their environment, it was aimed to enhance their awareness of environment and develop their spatial perception skills. These activities included:

- Performing enactments with drama method,

- Running a documentary to demonstrate several places and traffic rules,

- Conducting spatial perception exercises by applying images,

- Finalizing the course with questions and answers.

4) In the subject 'I Find My Direction', activities were performed not only about a limited area where the students live but also for making them get to know the entire nature and planet and explore universally-recognized information on environment, and exercises were done to develop their spatial perception skills. The last activity was turned into an interactive game and aimed to increase students' motivation and provide them with the ability to use what they learn in the right place. These activities included:

- Performing enactments with drama method about finding directions,

- Creating products about different places with the game designed,

- Presentation of the products and discussion with questions and answers.

Following the education performed by the classroom teachers with the experimental and control group students, LSAS and the open-ended perception questionnaire were administered again.

To mention the roles of the researchers in the study; while the first researcher fulfills all the scientific requirements of the article; the second researcher is responsible for the education given to the experimental and control groups. The first researcher is responsible for constructing the design of the article, analyzing the quantitative and qualitative data and writing all stages of the article. The second researcher also played a role in shaping the education given to the experimental group.

\section{Data Analysis}

Since numbers of students in the experimental and control groups were lower than 30, non-parametric tests were applied in the quantitative data analysis (Creswell, 2015). Mann-Whitney U and Wilcoxon Signed Ranks tests of parametric tests were performed in the study using the SPSS 22.0 software. The data obtained from the open-ended questionnaire in the qualitative part were subjected to a content analysis. The data obtained were associated with spatial perception skills in the Life Science curriculum and accordingly coded. Shared aspects of the codes were found, and subsequently, main and subthemes were created. In support of these themes, citations from student statements were included. Yet, students were coded as S1, S2, S3, and so on for confidentiality purposes. 
In the qualitative data analysis, a faculty member who specializes in qualitative data analysis provided assistance for inter-rater reliability. It was ensured that the data obtained from the open-ended questionnaire were coded again during the content analysis. Coding by the researchers and the expert was compared, and the inter-rater reliability formula by Miles and Huberman (1994) was applied. Agreement of the analysis between the researchers and the expert was calculated by the formula "Reliability=Number of Agreements/Number of Agreements + Number of Disagreements". According to Miles and Huberman (1994), the analysis is accepted to be reliable if the result is above \%70 (p. 64). Mean coefficients of researcher and expert analysis in the data analysis were found to be 0.94 for the pretest and 0.90 for the posttest. Accordingly, the open-ended questionnaire used in the study was determined to be reliable.

\section{Findings}

In this study, qualitative data are collected to further understand the quantitative data. For this reason, firstly quantitative findings and then qualitative findings are included.

\section{Quantitative Findings}

The difference between the experimental and control group scores of LSAS administered to measure the effect of the education on students' attitudes toward Life Science course is addressed in this section.

Difference between experimental group students' pretest and posttest scores of LSAS. LSAS was administered to the experimental and control groups to examine to what extent their pre- and post- education attitudes toward Life Science course differed. It was aimed to explore how the education performed with the two groups affected students' attitudes toward Life Science course. Accordingly, Wilcoxon Signed Ranks test results for the relationship between the pretest and posttest scores of LSAS administered to the experimental group are given in Table 3.

Table 3

Wilcoxon Signed Ranks Test Results for the Relationship between the Pretest and Posttest Scores in the Experimental Group

\begin{tabular}{llllllll}
\hline LSAS & $\mathrm{n}$ & Mean Rank & $\begin{array}{l}\text { Sum } \\
\text { Ranks }\end{array}$ & of & & $\mathrm{z}$ \\
\hline \multirow{5}{*}{ Directions } & Negative Ranks & 0 & .00 & .00 & $-3.306^{*}$ & .001 \\
& $\begin{array}{l}\text { Positive Ranks } \\
\text { Ties }\end{array}$ & 15 & 7.50 & 105.00 & & \\
& Total & 21 & & & & \\
\hline *hased on negative ranks & & & & & & \\
\hline
\end{tabular}

*based on negative ranks

As seen in Table 3, a statistically significant difference was found between the pretest and posttest mean scores of experimental group students' attitudes toward Life Science course $(\mathrm{z}=-3.306 ; \mathrm{p}<0.05)$. The data indicate that none of the student had lower scores in the posttest compared to the pretest, 15 students increased their scores in the posttest, and there were 6 students who got the same scores both in 
the pretest and posttest. This suggests that the education significantly improved the experimental group students' attitudes toward Life Science course.

Difference between control group students' pretest and posttest scores of LSAS. Wilcoxon Signed Ranks test results for the relationship between the pretest and posttest scores of LSAS administered to the students before and after the education with the control group are given in Table 4 .

Table 4

Wilcoxon Signed Ranks Test Results for the Relationship Between the Pretest and Posttest Scores in the Control Group

\begin{tabular}{llllllll}
\hline LSAS & & $\mathrm{n}$ & Mean Rank & $\begin{array}{l}\text { Sum } \\
\text { Ranks }\end{array}$ & of & $\mathrm{z}$ & $\mathrm{p}$ \\
\hline \multirow{5}{*}{ Directions } & Negative Ranks & 3 & 6.17 & 18.50 & $-.073^{*}$ & .942 \\
& Positive Ranks & 5 & 3.50 & 17.50 & & & \\
& Ties & 13 & & & & & \\
\hline & Total & 21 & & & & & \\
\hline
\end{tabular}

*based on positive ranks

According to Table 4, no statistically significant difference was found between the pretest and posttest mean scores of control group students' attitudes toward Life Science course ( $\mathrm{z}=-.073 ; \mathrm{p}>0.05)$. The data indicate that 3 students had lower scores in the posttest compared to the pretest, 5 students increased their scores in the posttest, and there were 13 students who got the same scores both in the pretest and posttest. It can be concluded that the education was not effective in increasing control group students' scores of attitudes toward Life Science course.

Difference between experimental and control group students' posttest scores of LSAS. Mann-Whitney $U$ test results for experimental and control group students' posttest scores in LSAS are presented in Table 5.

Table 5

Mann-Whitney U Test Results for Experimental and Control Group Students'Posttest Scores

\begin{tabular}{llllll}
\hline Group & $\mathrm{n}$ & Mean Rank & Sum of Ranks & $\mathrm{U}$ & $\mathrm{p}$ \\
\hline Experimental & 21 & 26.10 & 548.00 & \multirow{2}{*}{124.000} & \multirow{2}{*}{.013} \\
Control & 21 & 16.90 & 355.00 & &
\end{tabular}

Mann-Whitney U test was performed to see whether groups' attitudes toward Life Science course differed significantly after the education performed with the experimental and control groups. As seen in Table 4, mean scores of attitudes were found to be 26.10 for the experimental group and 16.90 for the control group. The difference between groups' attitudes scores was also found to be statistically significant $(\mathrm{U}=124.00, \mathrm{p}=.013, \mathrm{p}<.05)$. Accordingly, a significant difference was observed in scores of attitudes toward Life Science course in favor of the experimental group.

Comparing these data with the pretest results in Table 1, it is seen that experimental group's mean score of attitudes increased from 22.29 to 26.10 and control group's mean score of attitudes decreased from 20.71 to 16.90 . One can 
Ütkür Güllühan, N.; Emral, T. (2021). A mixed-design study on development of spatial perception...

suggest based on the data that the education performed with the experimental group significantly increased their attitudes toward Life Science course whereas the education performed with the control group caused a decrease in their attitudes.

\section{Qualitative Findings}

This section addresses the results of the open-ended questionnaire which was administered to provide a more detailed explanation of the findings achieved from LSAS and examine the relationship between the findings and spatial perception skills.

Pre- and post-education results of the open-ended perception questionnaire for the students in the experimental and control groups. Regarding the results of the open-ended perception questionnaire applied to the experimental and control group students before and after the education, a change in students' perceptions of "geography" was observed. The relevant data are given in Table 6 and 7.

Table 6

Experimental Group Students' Perceptions of Geography

\begin{tabular}{|c|c|c|c|}
\hline Questionnaire & Main themes & Subthemes & Number (f) \\
\hline \multirow{9}{*}{$\begin{array}{l}\text { Pre-education } \\
\text { perception } \\
\text { questionnaire }\end{array}$} & Unanswered & $\begin{array}{l}\text { Those who did not know the } \\
\text { answer } \\
\text { Those who left the question } \\
\text { unanswered }\end{array}$ & 6 \\
\hline & \multirow{4}{*}{ Course } & A course about students & 3 \\
\hline & & $\begin{array}{l}\text { A course similar to Science } \\
\text { course }\end{array}$ & 2 \\
\hline & & Course of learning language & 1 \\
\hline & & History course & 1 \\
\hline & \multirow{4}{*}{ Earth } & Something about the Earth & 2 \\
\hline & & Plants & 1 \\
\hline & & Animals & 1 \\
\hline & & Area where one lives & 1 \\
\hline \multirow{11}{*}{$\begin{array}{l}\text { Post- } \\
\text { education } \\
\text { perception } \\
\text { questionnaire }\end{array}$} & \multirow{5}{*}{ Earth } & World/Nature & 8 \\
\hline & & Environment & 4 \\
\hline & & Our country & 3 \\
\hline & & Place where one lives & 2 \\
\hline & & People & 2 \\
\hline & \multirow{2}{*}{ Course } & Life Science course & 8 \\
\hline & & History course & 1 \\
\hline & \multirow{4}{*}{ Location/direction } & Map/compass & 3 \\
\hline & & Directions & 2 \\
\hline & & Plots & 2 \\
\hline & & Location & 1 \\
\hline
\end{tabular}

It is understood from Table 6, the experimental group's perceptions of geography improved in the post-education questionnaire compared to the pre-education questionnaire. Whereas 10 students said in the pre-education questionnaire that they did not know the answer, or left the question unanswered, all students 
provided answers in the post-education questionnaire. It was also found that the answers provided in the post-education questionnaire were more associated with concepts such as "map/compass, directions, plots, location, place where one lives" in regard to spatial perception.

Table 7

Control Group Students' Perceptions of Geography

\begin{tabular}{|c|c|c|c|}
\hline Questionnaire & Main themes & Subthemes & Number (f) \\
\hline \multirow{4}{*}{$\begin{array}{l}\text { Pre-education } \\
\text { perception } \\
\text { questionnaire }\end{array}$} & Unanswered & $\begin{array}{l}\text { Those who did not know the } \\
\text { answer }\end{array}$ & 16 \\
\hline & \multirow{3}{*}{ Earth } & $\begin{array}{l}\text { Relationship between nature } \\
\text { and human }\end{array}$ & 2 \\
\hline & & Country & 1 \\
\hline & & Natural events & 1 \\
\hline \multirow{4}{*}{$\begin{array}{l}\text { Post-education } \\
\text { perception } \\
\text { questionnaire }\end{array}$} & \multirow{2}{*}{ Earth } & Nature & 8 \\
\hline & & World & 7 \\
\hline & Unanswered & $\begin{array}{l}\text { Those who did not know the } \\
\text { answer }\end{array}$ & 3 \\
\hline & Course & A course about human & 2 \\
\hline
\end{tabular}

The data obtained from the pre- and post-education perception questionnaires as shown in Table 7 suggest that there were more questions in the post-education questionnaire of which the students knew the answer. Compared to the experimental group, it is seen that the data indicate concepts about spatial perception skill at a lower level. The concepts such as "nature, world, country" were mentioned by the students about geography in general. Table 8 and 9 show the data about experimental and control groups' perceptions of spatial perception.

Table 8

Experimental Group Students' Perceptions of Spatial Perception

\begin{tabular}{|c|c|c|c|}
\hline Questionnaire & & Themes & Number (f) \\
\hline \multirow{3}{*}{$\begin{array}{l}\text { Pre-education } \\
\text { questionnaire }\end{array}$} & \multirow{3}{*}{ perception } & Those who did not know the answer & 19 \\
\hline & & Finding the space & 1 \\
\hline & & Perceiving a place & 1 \\
\hline \multirow{5}{*}{$\begin{array}{l}\text { Post-education } \\
\text { questionnaire }\end{array}$} & \multirow{5}{*}{ perception } & $\begin{array}{l}\text { Recognizing/knowing the } \\
\text { environment }\end{array}$ & 8 \\
\hline & & $\begin{array}{l}\text { Recognizing/finding/understanding } \\
\text { the space }\end{array}$ & 6 \\
\hline & & Knowing where it is & 4 \\
\hline & & $\begin{array}{l}\text { Knowing the characteristics of the } \\
\text { place where one lives }\end{array}$ & 2 \\
\hline & & $\begin{array}{l}\text { Recognizing about the country and } \\
\text { city }\end{array}$ & 1 \\
\hline
\end{tabular}

As seen in Table 8, experimental group students' perceptions of spatial perception changed substantially in the post-education questionnaire compared to the pre-education questionnaire. The students who reported that they did not know the answer provided answers particularly in the themes "recognizing the environment, recognizing the space, and knowing where it is" after the education. As for the student statements, in the theme "recognizing/knowing the 
Ütkür Güllühan, N.; Emral, T. (2021). A mixed-design study on development of spatial perception....

environment", S4 wrote, Characteristics around the space help us perceive it and know its characteristics." In the theme "Recognizing/finding/understanding the space", S12 and S18 provided their opinions, saying "For example, in spaces such as our classroom, school, we know and recognize the things there." and "We know and understand the things in the place where we live." respectively. It can be understood from the student statements that they had a grasp of the concepts regarding "what spatial perception is about" after the education.

Table 9

Control Group Students' Perceptions of Spatial Perception

\begin{tabular}{llll}
\hline Questionnaire & Themes & Number (f) \\
\hline $\begin{array}{l}\text { Pre-education } \\
\text { questionnaire }\end{array}$ & perception & $\begin{array}{l}\text { Those who did not know the } \\
\text { answer } \\
\text { Knowing the environment }\end{array}$ & 19 \\
\hline $\begin{array}{l}\text { Post-education } \\
\text { questionnaire }\end{array}$ & perception & $\begin{array}{l}\text { Knowing/recognizing the space } \\
\text { Recognizing the neighborhood } \\
\text { Knowing the location of classroom }\end{array}$ & $\begin{array}{l}10 \\
5\end{array}$ \\
\hline
\end{tabular}

Table 9 presents the data on control group students' perception of spatial perception before and after the education. Accordingly, whereas majority of the students stated that they did not know the answer in the pre-education questionnaire, it was not the case in the post-education questionnaire. The data included the themes "knowing/understanding the space, recognizing the neighborhood, knowing the location of classroom". The data were observed to be less diverse compared to the experimental group. In the theme "knowing and understanding the space", S15 wrote, "Spatial perception is, I mean, to know where the space is.", and S7 wrote, "It is to know the surroundings of our home.". Table 10 and 11 present the data on experimental and control groups' perceptions of plots as is a tool used in relation to spatial perception before and after the education.

Table 10

Experimental Group Students' Perceptions of Plots as a Tool for Spatial Perception

\begin{tabular}{llll}
\hline Questionnaire & Main themes & Subthemes & Number (f) \\
\hline & Unanswered & $\begin{array}{l}\text { Those who did not know the } \\
\text { answer }\end{array}$ & 6 \\
\cline { 2 - 4 } $\begin{array}{l}\text { Pre-education } \\
\text { perception }\end{array}$ & $\begin{array}{l}\text { Those who gave the } \\
\text { questionnaire }\end{array}$ & $\begin{array}{l}\text { Draw/drawing } \\
\text { Template }\end{array}$ & 4 \\
& & Seeing from above & 1 \\
& Those who guessed & Map & 3 \\
& the answer & Course about mathematics & 2 \\
& & Something useful & 2 \\
& & Indicator & 1 \\
& & Shape & 1 \\
\hline \multirow{3}{*}{$\begin{array}{l}\text { Post- } \\
\text { education } \\
\text { perception }\end{array}$} & Those who gave the & view from a bird's eye & 17 \\
questionnaire & correct answer & Finding the home address & 7 \\
& & Finding a place/direction & 5 \\
& & Small version of map & 4 \\
& & Locating the classroom & 3
\end{tabular}




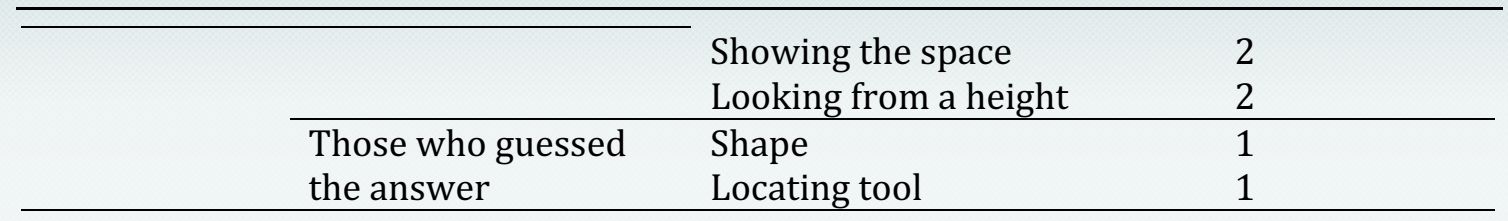

As understood from the data in Table 10, there were changes between experimental group students' answers about plots before and after the education. The data in the post-education perception questionnaire were found to have changed in connection with spatial perception skill. While there were 6 students who stated they did not know the answer in the pre-education questionnaire, all students were observed to provide answers about plots. The student answers were grouped as those who gave the correct answer and those who guessed the answer. Whereas majority of the pre-education answers included "drawing, map, course about mathematics, something useful", answers such as "looking from a bird's eye view, finding the home address, finding location/direction, showing the space" were observed after the education.

As for the student statements, S20 provided the following answer about looking from a bird's eye view: "We can see where we are if we look from above in the plot. For example, our neighborhood. It is the space where we live after all." Stating opinion about finding the home address and locating the classroom, S1 wrote, "For example, when we perceive the space, the plot shows the home and classroom, I mean, the place where we are at that moment. If our friend is at somewhere, we can find him/her, too." Considering the theme "showing the space", S7 provided the answer "I mean, it is a description of a space. I think so. For example, it is like how we would go to a market. We can see it on the plot." In the post-education answers of the experimental group, a positive change was observed for the association between plots and spatial perception.

Table 11

Control Group Students' Perceptions of Plots as a Tool for Spatial Perception

\begin{tabular}{lll}
\hline Questionnaire & Themes & Number (f) \\
\hline \multirow{3}{*}{$\begin{array}{l}\text { Pre-education perception } \\
\text { questionnaire }\end{array}$} & Those who did not know the & 10 \\
& answer & 8 \\
& Map & 2 \\
& Seeing the neighborhood up close & 2 \\
\hline \multirow{3}{*}{ Post-education perception } & Bird's eye view & 11 \\
questionnaire & Looking from above & 9 \\
& Drawing shapes & 3 \\
& Creating a template & 2 \\
\hline
\end{tabular}

As seen in Table 11, control group students' answers about plots changed positively compared to the pre-education answers. While there were students who did not know the answers in the pre-education questionnaire, it was found that all students provided answers in the post-education questionnaire. However, the student answers were limited to answers such as "bird's eye view, looking from above, drawing a shape, and creating a template". In the themes "bird's eye view" and "looking from above", S8 and S10 provided the following statements, 
respectively: "To give an example of plot, we can look at our neighborhood from a bird's eye view, from above." and "We are drawing shapes when drawing plots, and this makes me happy." In general, it was found that the student answers in the control group were not associated with spatial perception skill after the education. Table 12 and 13 show the data on experimental and control groups' post-education perceptions of which Life Science course subjects are related to spatial perception.

Table 12

Experimental Group Students' Perceptions of which Life Science Course Subjects are Related to Spatial Perception Skill

\begin{tabular}{|c|c|c|}
\hline Main themes & Subthemes & Number (f) \\
\hline \multirow{3}{*}{ Map using } & Pointing the whole world & 10 \\
\hline & Pointing the country & 8 \\
\hline & Pointing the city where one lives & 5 \\
\hline \multirow{3}{*}{ Plot using } & Finding the classroom & 10 \\
\hline & Finding the neighborhood & 7 \\
\hline & Finding the village & 2 \\
\hline \multirow{4}{*}{ Giving directions } & $\begin{array}{l}\text { Pointing the location/direction of places } \\
\text { around }\end{array}$ & 9 \\
\hline & $\begin{array}{l}\text { Recognizing and knowing the } \\
\text { environment }\end{array}$ & 7 \\
\hline & Finding friend's home & 4 \\
\hline & Finding directions at camp & 4 \\
\hline
\end{tabular}

Experimental group's post-education answers about which Life Science course subjects might be related to spatial perception skill are given in Table 12. It is seen that the student answers were concentrated in the main themes "map using, plot using, and giving directions". Majority of the answers about map using included "pointing the whole world, pointing the country". As for the student statements, S3 answered, "For example, when using map in the Life Science course, we played treasure hunt. We played and talked about and showed the spaces in the activity." The student answers about plot using were categorized under the groups of "finding the classroom" and "finding the neighborhood". In this theme, S1 answered, "Using the plot in the Life Science course, we perceive the space more easily by looking and finding what is in front of, behind, on the right side and left side of the place to where we will go." The final theme of student answers was "giving directions". The student answers were concentrated in subthemes "showing the location/direction of places around, recognizing and knowing the environment". In these subthemes, S5 wrote, "We can use a compass to find our direction at camp and learn about that space, that is, the nature."

One can argue based on the data that the experimental group students acquired certain concepts about spatial perception skill after the education. 
Table 13

Control Group Students' Perceptions of which Life Sciences Course Subjects are related to Spatial Perception Skill

\begin{tabular}{lll}
\hline Main themes & Subthemes & Number (f) \\
\hline Map using & Finding/pointing the neighborhood & 15 \\
\hline Plot using & Finding the classroom & 12 \\
\hline Giving directions & $\begin{array}{l}\text { Finding the direction in the } \\
\text { environment }\end{array}$ & 12 \\
\hline Unanswered & $\begin{array}{l}\text { Those who left the question } \\
\text { unanswered }\end{array}$ & 7 \\
\hline
\end{tabular}

Control group's post-education answers about which Life Science course subjects might be related to spatial perception skill are shown in Table 13. The student answers seemed to be concentrated in the main themes "map using, plot using, and giving directions". However, differently from the experimental group, 7 students left the questionnaire unanswered. Answers of the remaining students were mostly grouped in the subthemes "finding/pointing the neighborhood, finding the classroom, and finding the direction in the environment." For example, S12 answered, "Maybe the subject 'finding our neighborhood' in the Life Science course." and S9 wrote, "There is the subject 'finding your classroom and school on the plot'."

In light of all the answers provided by the students, it is possible to argue that the control group students acquired certain concepts about spatial perception skill at a relatively lower level compared to the experimental group students after the education.

\section{Result and Discussion}

It was aimed with this study to determine to what extent use of different methods in the instruction of geography subjects in Life Science course affect students' spatial perception skills. To that end, an open-ended questionnaire and LSAS was administered to the experimental and control groups before and after a education in geography subjects of Life Science course. The data indicate that the education performed with the experimental group had a more positive effect on students' spatial perception skills and also caused a significantly positive improvement in their attitudes toward Life Science course.

It was concluded that the education significantly improved the experimental group students' attitudes toward Life Science course. As for the control group, no statistically significant difference was concluded between students' pretest and posttest mean scores of Life Science course attitudes. Thus, it was concluded that the education performed with the control group was not effective in increasing students' scores of attitude toward Life Science course. This might have been caused by the fact that the geography subjects in the Life Science textbook were taught in accordance with the methods in the textbook one after another. It is thought that their attitudes were improved toward Life Science course because drama, case study, and several games and activities were applied in the experimental group. Similarly, Foran (2008) stated that the greatest problem in the courses of social 
sciences today is that teachers and students are usually dependent on and limited to the textbook. Moreno-Vera and Alvén (2020) also mentioned the negative aspects regarding the instruction of geography subjects in primary school with a rotelearning method. The researchers stated that active learning methods would positively affect thinking levels of students in social sciences classes and allow for more effective instruction of geography subjects. A parallel result was achieved by Akar (2008) who concluded that students could not improve their geographical knowledge sufficiently as they only memorized the information, did not put it into practice and did not study it on map enough. It was also stated in the relevant study that lack of activities on map literacy in Social Studies workbooks negatively affected the development of this skill. Correspondently, it was concluded in the present study that the education provided for the control group with the coursebook methods developed students' spatial perception skills at a lower level compared to the experimental group.

Based on the data obtained in the open-ended perception questionnaire, one can argue that the experimental group students acquired certain concepts about spatial perception skill after the education. It is also possible to say that the control group students acquired certain concepts about spatial perception skill at a relatively lower level compared to the experimental group students after the education.

In the post-education perception questionnaire, answers of the experimental group students about geography concepts included "map/compass, directions, plots, location, place where one lives" which are related to spatial perception skill. In the control group, answers were limited to concepts such as "nature, world, country" without any mention of concepts related to spatial perception skill. The reason might have been the fact that the education was performed with the control group according to the textbook and real-life cases and activities were not used. A parallel result was achieved by Ablak and Aksoy (2018) in a study which aimed to determine how spatial perception skill was perceived by students. It was observed in the said study that few students developed metaphors which included elements to improve spatial perception such as map, globe, navigation, etc. Based on these results, Ablak and Aksoy (2018) recommended to further apply such elements to provide retention of spatial perception skill among students. It was also stated that practices should be performed with students in the real-life settings to benefit from those elements more.

It was observed that experimental group students' answers about plots as a tool related to spatial perception in the post-education questionnaire changed in connection with spatial perception skill. Post-education answers included "looking from a bird's eye view, finding the home address, finding location/direction, showing the space". Yet, control group students' answers were limited to answers such as "bird's eye view, looking from above, drawing a shape, and creating a template". In general, it was found that the student answers in the control group were not associated with spatial perception skill after the education. This might have been caused by the fact that the students could not be made understand the association between plots and spatial perception skill in the education performed with the control group. Indeed, the answer "Using the plot in the Life Science course, we perceive the space more easily by looking and finding what is in front of, behind, on 
the right side and left side of the place to where we will go." provided by one of the experimental group students about plots shows that the association between plots and spatial perception skill was addressed in this group.

It is understood that answers both in experimental and control groups about which Life Science subjects might be related to spatial perception were concentrated in the main themes "map using, plot using, and giving directions". The themes seem to coincide with the subskills of spatial perception skill in the 2019 Life Science curriculum (MoNE, 2018). This result shows that the educations performed with the experimental and control groups were effective in helping students acquire spatial perception skill. However, higher number of answers and more detailed answers were received in the experimental group compared to the control group, which suggests that the education with the experimental group was more effective than the one with the control group.

Overall, as indicated by the results, subskills such as "map using, plot using, and giving directions" are important enough to remain in students' minds. Students of both groups provided answers and examples about these skills in almost every question. It is also stated in the literature that these subskills are about spatial perception especially in Social Studies course and how important they are. There are studies in the literature on the importance of map using (Akengin, Tuncel \& Cendek, 2016; Kızılçaoğlu, 2007; Kuzey, 2017; Pala \& Başıbüyük, 2020; Sönmez \& Aksoy, 2013; Witham-Bednarz, Acheson \& Bednarz, 2006); plot using (Bahar, Sayar \& Başıbüyük, 2010) and finding directions (Demirbaş, Aydınözü \& Demir, 2020; Demirkaya, Çetin \& Tokcan, 2004). Nearly all of those studies emphasize the importance of applying them along with activities which will activate students. As suggested by the studies, this should enable students to acquire spatial perception skill more properly and efficiently.

In light of the results overall, one can argue that use of several methods and activities which would activate student in the classroom environment have a positive impact on students' spatial perception skills and attitudes toward Life Science course.

Limitations of this study are listed below:

- The study was limited to 42 third-graders studying in two classes of a public primary school on the European side of İstanbul province.

- The education provided in the study was limited to four learning outcomes chosen from the primary school third-grade Life Science course.

- The education was limited to eight hours in total.

- There is no pilot application for the training used in the study.

- Since it is a pandemic period, it is limited to online education.

\section{Suggestions}

The following recommendations can be made for future studies:

- Most of the studies in the literature were observed to focus on spatial perception skill in Social Studies course. Thus, it is recommended to carry out a longitudinal study that starts in the third-grade Life Science course and 
continues in the fourth- and fifth-grade Social Studies course. This way, it can be explored whether students will acquire the spatial perception skill in the long term.

- It is important that teachers teach geography subjects in Life Science and Social Studies courses in a qualitative manner. To that end, in-service educations can be offered to teachers so that they can develop such educational programs and improve their quality.

- It is understood from the student answers that spatial perception starts from the immediate surroundings. The students both in the experimental and control groups wrote about spaces in the order that goes like "neighborhood, city, and country". Hence, given the importance of family in the perception of immediate surroundings, future studies can be performed with students and their families.

- This study was conducted in the mixed design using both quantitative and qualitative methods. In future studies, use of an exhaustive qualitative design such as action research can provide additional data. By this means, more detailed data should be obtained using qualitative data collection instruments such as student diaries, observations, and interviews.

\section{References}

Ablak, S., \& Aksoy, B. (2018). Investigation of student perceptions related to spatial perception skills in social studies program. Turkish Studies Educational Sciences, 13(11), 1-32.

Akar, B. (2008). The evaluation of the map using ability of $6^{\text {th }}$ grade students and the evaluation of the thoughts of teachers about the map using abilities of students. (Unpublished master thesis). Mustafa Kemal Üniversitesi, Sosyal Bilimler Enstitüsü, Mersin.

Akengin, H. Tuncel, G., \& Cendek, M. E. (2016). The social sciences teachers' opinions about developing map literacy of students. Journal of Marmara Geography, 34, 61-69.

Aktürk, V., Yazıcı, H., \& Bulut, R. (2013). The effects of the use of animations and digital maps in social studies on students' spatial perception skills. Journal of Marmara Geography, $28,1-17$.

Bahar, H. H., Sayar, K., \& Bașıbüyük, A. (2010). The study of sketch map reading skills of the students in primary school (Erzincan sample). Firat University Journal of Social Science, 20(1), 229-246.

Brooks, J. G., \& Brooks, M. G. (1999). In search of understanding the case for constructivist classrooms. Virginia: Association for supervision and curriculum development.

Christensen, L. B., Johnson, R. B., \& Turner, L. A. (2015). Research methods design and analysis. A. Aypay (Trans Ed.). Ankara: Anı.

Creswell, J. W., \& Plano-Clark, V. L. (2015). Designing and conducting mixed methods research. Y. Dede \& S. B. Demir (Trans. Eds.). Ankara: Anı.

Demirbaş, İ., Aydınözü, D., \& Demir, F. B. (2020). Classroom teachers' opinions on gaining gains related to direction and direction finding in primary school students. International Journal of Geography and Geography Education, 41, 59-72. 
Demirkaya, H., Çetin, T., \& Tokcan, H. (2004). The methods that can be used in teaching the concept of direction in primary education. Gazi University Journal of Gazi Education Faculty, 24(3), 39-70.

Eaton, D. (1998). Cognitive and affective learning in outdoor education. (Unpublished doctoral thesis). University of Toronto, Canada.

Foran, A. (2008). An outside place for social sciences. Canadian Social Sciences, 41(1), 1-9.

Kızılçaoğlu, A. (2007). A pedagogical view to mapping skills. Selçuk University Journal of Social Sciences, 18, 341-358.

Kuzey, M. (2017). The literacy of map and direction from the proclamation of the republic to today for the social of life educational programs. Journal of Kazım Karabekir Education Faculty, 34, 1-18.

Kuzey, M. (2020). Preservice teachers' metaphors about the concept of space perception. Review of international geographical education (RIGEO), 10(1), Special Issue, 140-158.

Miles, M. B., \& Huberman, A. M. (1994). An expanded sourcebook qualitative data analysis. London: Sage Publications.

Ministry of National Education [MoNE], (2005). Life science course curriculum: $1^{\text {st }}, 2^{\text {nd }}$ and $3^{\text {rd }}$ grades. Ankara: Ministry of National Education Publishing.

Ministry of National Education [MoNE], (2018). Life science course curriculum: $1^{\text {st }}, 2^{\text {nd }}$ and $3^{\text {rd }}$ grades. Ankara: Ministry of National Education Publishing.

Moreno-Vera, J. R., \& Alvén, F. (2020). Concepts for historical and geographical thinking in Sweden's and Spain's Primary Education curricula. Humanities and Social Sciences Communications, 7(107), 1-10. https://doi.org/10.1057/s41599-020-00601-z

Pala, Ş., \& Başıbüyük, A. (2020). Investigation of geography and social sciences curriculum in terms of map skills. Review of International Geographical Education (RIGEO), 10(1), Special Issue, 84-96.

Parker, W. C. (2001). Social studies in elementary education. New Jersey: Merrill Prentice Hall.

Safi, H. (2010). Teachers' opinions about the spatial cognition skills (Unpublished master thesis). Marmara University, Istanbul.

Schunk, D. H. (2011). Learning theories an educational perspective. M. Y. Demir (Trans. Ed.). Ankara: Nobel.

Sönmez, Ö. F., \& Aksoy, B. (2013). Map skills and present of republic elementary school curricula. The Journal of Turkish Social Research, 17(1), 269-288.

Tümertekin, E., \& Özgüç N. (2004). Human geography: human-culture-space. İstanbul: Çantay Bookstore.

Witham-Bednarz, S., Acheson, G., \& Bednarz, R. S. (2006). Maps and map learning in social studies. Social Education 70(7), 398-432.

Yurdugül, H. (2005). Use of scope validity indexes for scope validity in scale development studies, XIV. National Educational Sciences Congress, (s.1-6). Denizli: Pamukkale University, Turkey.

Zayimoğlu-Öztürk, F., \& Coşkun, M. (2015). Developing an attitude scale towards life studies lesson: validity and reliability study. International Journal of Turkish Education Sciences, 4, 239-255. 


\section{Biographical Statements}

Nur ÜTKÜR GÜLLÜHAN is an Associate Professor at the Hasan Ali Yucel Education Faculty in Istanbul University-Cerrahpaşa, where she is Primary School Education Department. Her research interest includes Social Studies education, Life Science Education, Geography Education, teaching methods and techniques, creative drama.

Tuğçe EMRAL is a primary school teacher at the Ministry of National Education, Istanbul. Her research interest includes Life Science Education and Geography Education. 